\title{
Are Retailers "Bagging” the Carrier Bag Levy in England? An Exploratory Enquiry
}

\begin{abstract}
This paper examines the business impact of the legislation in England requiring retailers to charge consumers for single-use carrier bags. The legislation impacts three key stakeholders - Government, retailers, and consumers. The primary focus of this study is, however, from the perspective of retailers and how this group of stakeholders may have benefitted from the charge. Retailers are using the collected revenues to promote their image in the marketplace and presenting themselves as corporate social responsible entities. For retailers, the charge provides an avenue for bolstering their carbon footprint as consumers are expected to reuse their plastic bags - i.e. the "bag for life" as they now have to pay for them. At the same time, the proceeds are helping some retailers to top up their coffers which to some extent implies that there is some misuse or abuse of the policy by retailers.
\end{abstract}

Keywords: Sustainability; Carrier Bag Levy; Retailers; Business Ethics; Corporate Social Responsibility

\section{Introduction}

Multinational retailers are perceived as business entities with strong influence, and their decisions can affect the whole economy. To increase their market competitiveness and achieve sustainable development these retailers engage in corporate social responsibility (CSR) practices and strategies, which are aimed at different stakeholders including consumers. Retailers realize that the key drivers for consumer purchasing decisions involve paying special attention to sustainability as it fosters consumers' trust in the company and the products they offer in the marketplace (Nielsen 2015). Reinforcing this view, Porter and Kramer (2006) claim that CSR activities contribute directly to company competitive advantage, and therefore should be part of the company overall strategy. Overall, adopting an inclusive CSR strategy is deemed to bring multiple benefits and synergistic effects to companies operating in the retail sector. 
This study investigates the impact of the British Government's legislation of a five pence (i.e. 5 p) charge for the use of carrier bags on mainstream retailers ${ }^{1}$ in England and how this new levy is affecting the retailers' CSR. The levy was introduced in October 2015, ${ }^{2}$ and major retailers have implemented the minimum $5 p$ charge on their carrier bags. The rationale for the Government is that the initiative would curtail or "...reduce the use of single-use plastic carrier bags, and the litter associated with them" (Department for Environment, Food and Rural Affairs 2017), and encourage a more environmentally-friendly behavior amongst consumers. A similar scheme which was introduced in October 2014 achieved cuts in carrier bag usage of up to $80 \%$ in Scotland, Wales and Northern Ireland (also see Thomas et al. 2016). With the carrier bag levy, the Government also expects to save billions in environment costs (mostly caused by carrier bags) over the long run and benefits for the environment.

The carrier bag levy has brought about certain desirable environmental benefits, particularly in reducing pollution. Statistics published on the UK Government website suggest that 7.6 billion single-use carrier bags were handed out to customers by the major British supermarkets in 2014. Given the non-biodegradability of these bags as well as their adverse effect on landfill content, they represent a huge danger to the environment. The levy/charge is expected to counter this source of pollution. In its revised carrier bags policy paper, the Government notes that the levy has led to an $80 \%$ reduction in the usage of singleuse carrier bags (Department for Environment, Food and Rural Affairs 2017). ${ }^{3,4}$ The success of such levies is still debated in the literature. For instance, Convery et al. (2007) and Park (2009) argue for the effectiveness of the carrier bag levy in improving consumer behavior towards the environment.

The legislation as published on the Department for Environment Food \& Rural Affairs of the UK Government and released on GOV.UK ${ }^{5}$ states that there is a legal requirement on retailers with 250 employees or more (at the company level rather than the

\footnotetext{
${ }^{1}$ The focus on the retail industry as a business case for this study is based on the importance of the sector in influencing the customer behaviour towards environment (Durieu, 2003) and its significant role in reducing the environmental damage (United Nations Environment Programme, 2003). There is also an increase in the pressures imposed by regulators, customers and other stakeholders for retailers to enhance their environmental performance by being greener and environmentally friendly as documented by Lai et al. (2010), and Sivagnanasundaram (2018).

${ }^{2}$ The Act is named as the Single Use Carrier Bags Charges (England) Order 2015. Also see Gosden (2015).

${ }^{3}$ A recent study by Rivers et al. (2017) shows that the introduction of plastic bags levy in Toronto had less effect on less frequent users of reusable bags and those individuals with less social-economic rank. They conclude that nudging policies have their own limitations and do not produce exactly the expected results.

${ }^{4}$ Also see Chow (2016).

${ }^{5}$ Source: https://www.gov.uk/government/publications/single-use-plastic-carrier-bags-why-were-introducingthe-charge/carrier-bags-why-theres-a-5p-charge
} 
branch level) in England to charge $5 p$ for all single-use plastic carrier bags starting on 05 October 2015. The goal of the levy is to reduce the consumption of single-use plastic bags. It is hoped that the act of paying for these bags will cause customers to reuse them and reduce their impact on the environment since shoppers will not pay the charge if they reuse the bags. Shoppers can avoid the charge altogether by purchasing thicker, reusable 'bags for life' which can be exchanged for free when they are worn out. In the long term, the UK government intends to roll out the plastic bag charge to all UK retailers and not just the big ones.

The legislation provides instances where retailers are not required (although the law does not prohibit them) to apply the charge, i.e., paper bags, shops at airports, or on board trains, airplanes and ships, bags to wrap food, raw meat and fish or to account for a food safety risk, bags for prescription medicines, uncovered blades, seeds, bulbs and flowers, or live fish. There is currently no exemption for biodegradable bags but this may change in the future.

Since the charge is not a tax, the government does not collect it. However, there is an expectation that retailers will give the proceeds to good causes to be determined by them. The government asks retailers to report the usage of the money to publish an annual summary. For example, between April 2016 and April 2017, nearly two-thirds of retailers donated $£ 66$ million to good causes. Through the reports, the government and the retailers can track the usage of plastic bags and the effectiveness of the charge.

The legislation is not as clear-cut as to how retailers should use the proceeds from the carrier bags, and some retailers try to circumvent the levy to retain (or 'bag') the extra cash. While this might sound rather savvy, the fact remains that the proceeds of this extra revenue stream do not go to the Government coffers directly; instead, the retailers are expected to keep a record and make donations to charitable causes. There is a common assumption that income from the sale of carrier bags should be invested in corporate social responsibility(CSR) related activities; though, every supermarket seems to have its policy on what proportion of these funds are dedicated to CSR activities. These discrepancies in the behavior of retailers beg the question as to whether the proceeds from the $5 p$ carrier bag levy are having the desired social impact as intended by the Government, and whether its intended effects will hold in the long run.

Research so far - and at least in England - does not show how retailers are using the scheme to their benefit, dealing with the related day-to-day issues, and managing the collected revenues. From a societal marketing perspective, retailers should also contribute to 
solving social problems. However, little evidence exists in this particular area, a fact also emphasized by Bondy et al. (2012).

This study attempts to gain insights into the issues above which, to our knowledge, are currently unanswered. We use a range of qualitative data and research approaches consistent with Zen et al. (2013) to examine the issues related to managing the carrier bag levy. Theoretical studies related to CSR are also incorporated in the analysis of the data collected following Carroll (1991), and Garriga and Melé 2004. The data include information on the retailers' approach towards the levy implementation and the usage of the collected funds. The main sources of data are online and press reports, companies' websites, and related academic studies. The data interpretation is mainly driven by the study's theoretical framework and the application of thematic analysis.

Following this introductory section, the study reviews the literature on single-use carrier bag charges in the context of other regions that have implemented the charge before its implementation in England. This is followed by the research design, discussion of findings, conclusion, and limitations of the present study.

\section{Literature Review}

Research examining the impact of the $5 p$ carrier bag levy charge is still in its infancy and quite spread out as the scope of the levy has implications for several disciplines. However, some early evidence is emerging to show some mixed results around the success of the levy — varying among the Government, consumers, and retailers. The carrier bags' levy exists in other contexts outside England and has attracted scholarly attention as a consequence. As per Convery et al. (2007), the carrier bags' levy is among the various forms of tax aimed at improving the environment and combating pollution. The theoretical foundation of environmental taxation is rooted in the works of Pigou (1920). This was then followed by many studies which explored environment charges and taxation in different contexts such as fuel and energy (Bourgeon and Ollivier 2012; Miranda and Hale 2002; Sælen and Kallbekken 2011), climate change (Feng et al. 2010), carbon emissions (Ekins and Barker 2001), and foreign aid (Chao et al. 2012). These studies concur on the benefits of using taxes to render individuals and institutions alike directly accountable toward the environment.

Research, however, has shown that individuals, in particular, respond differently to the instruments introduced by the governments as a means to improve the environment 
(Ekins and Speck 1999). Individuals, for instance, are more receptive to tax than other incentives designed to tackle environmental concerns in the society, for instance, the deposit refund system used in recycling in some countries (Anstine2000). According to the Economist (2015), around six out of ten people are in favor of the 5p charge. Thus, the public welcomes the carrier bag levy. The long-term effectiveness of introducing certain environmental taxation such as the levy on carrier bags is still questioned though (Dikgang et al. 2012). Furthermore, Ayalon et al. (2009) assess the carrier bag regulation in Israel and conclude that the environmental impact caused by using free carrier bags is more of a political issue than an environmental one.

In Europe, many countries such as Ireland, Denmark, the Netherlands, Germany, Norway, Portugal, Switzerland, Spain, and Sweden use tax on carrier bags to reduce waste and improve the environment (Luís and Spínola 2010). However, the approach taken differs by country as well as the amount of the levy. In Portugal (Madeira Island), for instance, the cost was symbolic with only two cents charged per bag while Ireland set the cost at 15 cents in 2002 and then increased this to 22 cents in 2007. The reduction of using carrier bags attained in Portugal (Madeira Island) was $27 \%$ while a $90 \%$ reduction was achieved in Ireland. These results indicate that the charge applied to bags can affect people's attitude toward carrier bag usage. In their examination of the carrier bag levy introduced in South Africa in 2003, Dikganget al. (2012) conclude that the effectiveness of the levy declines after an initial but limited success. The authors argue that "as people became accustomed to paying for bags, the demand continued to climb."

A study by the Ministry of Environment and Food of Denmark Environmental Protection Agency (2018) argues that reusing the carrier bag as a waste bin bag is more beneficial than throwing it away or recycling it. Recycling is a better option for heavier plastic bags while reuse is more useful for light carrier bags. The study also compared the adverse environmental impacts by different types of carrier bags and finds the regular light carrier bags available in Danish supermarkets (as opposed to heavier carrier bags as an example) is the least detrimental to the environment similar to unbleached paper and biopolymer bags.

The discussion above suggests that while the carrier bag levy is helping in the fight against pollution, it is not necessarily eliminating it. It would be rash to expect that the levy will fight off pollution and change consumer habits completely. Nonetheless, it should dawn on the stakeholders that more needs to be done in this area to achieve a significant and sustainable decline in carrier bags' usage. 
This study, however, is concerned with the extra money gained by the retailers from the levy. This money does not go into Government coffers to fight the sustainability battle. While retailers are expected to channel this extra revenue to corporate social responsibility (CSR) activities, they are not legally bound to do so.

To the extent that the Government reports how the retailers have spent the carrier bag levy, there is some accountability and transparency on that expenditure. However, stores selfreport this expenditure item to the Government agency and they are afforded great discretion on how they report. In so far as the levy is expected to recast shoppers to become more environmentally conscious, then retailers and the Government should deliberate how their reporting activity can be improved to build trust amongst shoppers. Accountability is important in trust-building and changing attitudes (Forrer et al. 2010; Roberts 2001; Swift 2001 ) - particularly in the light of sustainable development practices.

This study notes that the post-levy carrier bags are here to stay (irrespective of the levy's success or not in curtailing carrier bags'usage). We argue that post-levy, the carrier bags have assumed two important uses: (i) consumers pay more attention to them since they are no longer free, and (ii) retailers are using the renewed customer attention to highlight their marketing messages on the carrier bags. The stores use the bags to flaunt their green credentials and, in the process, they influence public perception favorably.

Besides helping the Government to achieve its aims, the introduction of the carrier bag charge has been a marketing boon for stores. Certainly, the carrier bags that customers must pay $5 \mathrm{p}$ for are better designed, more attractive and of better quality. The Government refers to these bags as the "thicker reusable" ones. Stores have taken the opportunity to redesign these carrier bags more elegantly to serve as a marketing tool. Now that customers have to pay $5 \mathrm{p}$ for the carrier bag, they tend to use the bags more wisely; that is, shoppers ascribe more value to the bags than when they were available for free. Consequently, customers give more importance to the design and quality of the bag and, in the process, also pay more attention to the store's advert on the bag. Any design that the stores place on those bags is more noticeable and directly appeals to customers.

The scheme also comes at a cost to retailers. According to the Department for the Environment, Food and Rural Affairs (DEFRA) other costs related to the scheme include changing the till system, staff training, communicating the new policy to customers and staff, plus getting further advice from experts. However, these costs are expected to be minimal in comparison to the revenue raised from the sales of the carrier bags. The scheme has enabled retailers to generate extra revenues, bearing in mind the production/purchasing costs of these 
bags, staff costs, other costs related to the implementation of the scheme (as listed above), and giving the rest for a good cause. This goodwill gesture is expected to help retailers improve their image amongst consumers.

While most papers evaluate the carrier bag levy from environmental, public policy or consumer behavior perspectives, we explore the situation from a different angle. The primary focus of this study is from the perspective of retailers and how this group of stakeholders may have benefitted from the charge or misused the levy. For retailers, the charge provides an avenue for bolstering their carbon footprint as consumers are expected to reuse their carrier bags - i.e. the "bag for life" - as they now have to pay for them.

Overall, the levy has multiple positive effects. Notably, the reduction - not elimination - of pollution is only one of them. Customers seem to engage more with the retailers in terms of customer relationship management whereas at the same time retailers reduce their operational and overall costs. Although information from retailers is not easily available, the unethical behavior could have a negative impact on their image. Thus, the bag levy paved the way for the UK retailers to capitalize on the promotion of CSR outlook.

\section{Study Theoretical Framework}

The study's conceptual framework, as noted in the earlier section, is based on three key areas all related to the implementation of the carrier bags' levy by supermarkets. These are a) accountability, b) CSR, and c) scheme income allocation. In terms of CSR, it is pertinent to discuss the evolution of this concept and its recent alleged transition to the recent theory of Created Shared Value (CSV). To have a better understanding of the use of the legislation on carrier bags by retailers and the implications of the different approaches that have been adopted by the sector when they try to reduce environmental impact and to minimize pollution the two concepts are also discussed in the context of sustainability.

\section{Creating Shared Value and Communities}

Many retailers have historically contributed to the financing of social projects that benefit local communities where they operate. In fact, a study by Jones et al. (2005) found that the biggest UK retailers are increasingly engaging in activities supporting communities in which they operate. These authors provide interesting examples explaining how this may have positive effects on the beneficiaries but it is arguable how this is only having short- and mid- 
term outcomes for the communities. If firms want to have a long-term impact on their communities, they should consider other approaches that go beyond donation activities.

However, embracing the rationale of going beyond the mere participation in punctual activities such as sponsoring or donations, Porter and Kramer (2011) introduced the concept of Creating Shared Value (CSV). They challenged the academic literature and companies CSR practices. These authors claim that firms have better ways of integrating social goals without diverting their focus from their primary goal of being profitable. The starting point of their argument is people's perceptions about the role of firms: a) they prosper at the expense of communities; b) firms have myopic short-termism, and c) mistrust in businesses. They affirm that the purpose of the firm must be not just profit per se. They do not consider shared value as redistribution of value but as expanding the total pool of economic and social value.

Three forms of creating shared value are suggested by Porter and Kramer (2011): reconceiving products, redefining productivity in the value chain, and enabling the development of local clusters. First, in reconceiving products, managers review the main aspects related to products. This is relevant to our research, as retailers use carrier bags as a means to influence their sales and to expand their market share. Second, redefining productivity in the value chain applies to this study as the externalities should enhance the profitability of the supermarkets and add value to the wider society (e.g., by contributing to solving environmental challenges).

In this context, corporations are believed to be able to combine productivity with societal problems (Rocchi and Ferrero 2014). It might seem that CSV is just a quid pluris of CSR but, according to Rocchi and Ferrero (2014), the main difference between CSR and $\mathrm{CSV}$ is the place that these two pivotal areas occupy within the business process. CSR is considered as a discretionary practice; often the result of responses to external pressures and, in many cases, also disconnected from the core business, while CSV tries to integrate these responsibilities into a firm's strategies and its production processes.

CSV should be analyzed with the perspective of the firm's competitive advantage, a term coined by Porter (1987) and Porter and Kramer (2011) who consider that society needs to be fully integrated into the firm strategy. This recent interpretation of CSV is not exempt from criticism. For example, Crane et al. (2014) argue that synchronized creation of social and economic value is not something new and they do not accept CSR as an outdated concept. Like CSR, CSV has two facets - firm profit and societal good; the latter generates environment and ecological benefits. Attempts to integrate both elements of CSV allow firms to deliver on goals of sustainability more consistently. 


\section{Carrier Bag Levy and Sustainability}

It is expected that the carrier bag levy will contribute into the overall good of the society. To attain this, the levy should be used as a mean to improve sustainability. This perception is underpinned by cause-related marketing proposition (Varadarajan and Menon 1988) in which the corporate brand is associated with its ethical and social responsibilities. Introducing the term 'triple bottom line', Elkington (1994) reiterates the Report of the World Commission on Environment and Development $(1987)^{6}$ and considers a new development as sustainable when the needs of the present are met without compromising those of future generations. This is attained by ensuring a balance between three dimensions - environmental, social, and economic. In a later study, Bansal (2005) affirmed that these dimensions are interdependent and can reinforce each other.

Exploring the issue of sustainability, Jones et al. (2005) studied the top 20 retailers in the UK by reviewing the content of their CSR reports. In the discussion of their study, they noted that most major retailers are addressing sustainability and recognize the impact of their companies'activities on the environment. They concluded that sustainable development is a high priority in the UK retail industry.

This special interest given to sustainability is reinforced by increasing consumers', trade unions' and investors' awareness, raising media attention and introducing new legislation. An example of this development is the launch of a plan named "Towards retail sustainability" by the British Retail Consortium (BRC) in 2001 with one of its main goals being to stimulate a sustainable retail sector. The carrier bag levy is also among the legislation introduced to induce retailers to employ strategies that would minimize the negative impact of their activities on the environment.

Despite the increased attention on CSR and regulatory changes in recent years, however, there is still a lack of understanding about how these changes affect the retailer's customer strategy and the customers' attitude towards this new development. For this reason, the presented research offers fresh insights into these issues by unveiling retailers' strategic approach in implementing Government legislation on the carrier bag levy. Scholars have consensually viewed CSR as highly significant in modern businesses. For instance, Mann et al. (2014:2) note that "ninety-four percent of consumers in the world's largest countries want more of the products, services, or retailers they use to support worthy social and

${ }^{6} \mathrm{The}$ report can be accessed at http://www.un.org/documents/ga/res/42/ares42-187.htm 
environmental issues" (cited in Cone Communications \& Echo 2012: 5). Due to the growth of ethical consumerism and subsistence of social issues (Shaw et al. 2006), there has been increased pressure on companies to develop and communicate socially responsible programs that deals with ethical issues such as workers' rights and the environmental impacts of their businesses (Antal et al. 2002; Mamic 2008). As CSR practices are linked to companies' business performance and reputation, corporations have over the years tried to manage their own CSR and invest in their supply chains by imposing codes of conduct which enables them to maintain their sustainability in the global market (Rondinelli and Berry 2000).

In a similar vein, precautionary environmental approaches are seen to be providing benefits (Tickner and Geiser 2004). Therefore, these companies communicate their activities as a marketing benefit (Mann et al. 2014). In addition, raising the significance of good reputation reinforces the improvement of communication of these CSR initiatives (Dickson et al. 2009). This provides a case for the carrier bag levy as a CSR tool used to bridge the gap between the retailers and their clients.

\section{Research Approach/ Method}

The study follows a four-step approach in administering the research process. First, the academic literature is critically reviewed, and the findings pertinent to our study are collected. Second, press and media articles are reviewed to gather key insights. In many instances, direct quotes from the media sources are used to support the statements made. Third, some of the insights presented are the authors' observations from visits to the stores. Fourth, online published reports by the 15 largest retailers in England on the carrier bag levy are reviewed. The 15 retailers included in the study are (in no particular order) Tesco, Sainsbury, Asda, Morrisons, Marks \& Spencer, Cooperative Group, Waitrose (including partner John Lewis), Boots, Aldi, Home Retail Group, Next, Primark, Iceland, Lloyds Pharmacy, and Wilkinson-all from the UK.

The newspapers articles and reports were published by official government bodies including the Department for Environment, Food and Rural Affairs; trade associations such as the British Retail Consortium; organizations directly involved in corporate social responsibility and environmental related matters (i.e. CONE and EcoWatch); and daily newspapers with have high level of authenticity in the public domain (i.e. Telegraph). These articles and reports are independently written by industry experts and in line with the mission given to each body and institution as per the regulations set by the authorities. The period 
covered for the analysis of these news articles and reports is from the time of the initiation of the carrier bag levy, October 2015, to July 2018.

All the online reports published by the main retailers on the implementation and usage of the carrier bag levy are critically analyzed (see Table 1). The information presented in these online reports is verified based on retailers' financial reports, relevant government documentation and guidelines that the retailers need to comply with (i.e. retailers' responsibilities for the use of carrier bag charges) and the organizations and charities which receive grants or other financial support under the scheme. The reliability of the reports is also based on the remits that retailers are expected to be fully compliant regarding information disclosure and ethical standards set by the relevant regulatory bodies.

To further ensure that the review of the articles and reports is rigorous the research team followed a three-stage screening process. First, two authors identified the reports and articles published on the carrier bag levy since its initiation and source of publication. The first draft of the review of the reports and articles then produced. Second, two other authors critically examined the content of the draft and excluded any anomalies in the analyses of the reports and articles. In the final stage, a separate author mapped the analyses produced with relevant literature and eliminated any discrepancies in the interpretation of the collected data.

In addition to the review of the relevant reports, casual observations were carried out at large retail stores to observe their actual approach in implementing the scheme. The total number of observations completed is 20 at six different supermarkets (groceries), and two department stores (clothing and household items) - the stores cannot be named to preserve their confidentiality - with an average time of 15 minutes being spent on each occasion over a period of 3 months. The observations were conducted in multiple cities from eight different counties at different times during the day. The narrative presented in the discussion section is the authors' interpretation of what has been observed and is not supported or validated by a specific statistical data.

Scholars in different fields including environment and management support the use of observations as a form of research methodology (see for instance: Oliver and Eales, 2008; Tedlock, 2000). Gunn and Løgstrup (2014) assert that observation is a way to produce constructive critic while Oliver and Eales (2008) perceive observation as an approach to provide insights about the organization and to identify the actual problems faced at the specified time and situation. Through observations, a researcher can have a deeper understanding of the phenomena being investigated (Tedlock, 2000). Referring to the relevant literature on using observations as research methodology Hayes and Baker (2014: 
420-21) note that they enable investigators to have a close view of what has been practiced and to draw differences between someone expectations and what takes place within the organization. It is along these lines that we have decided to include observations alongside the review of articles and reports in order to have a deeper understanding of the implementation of the carrier bag levy scheme.

The study's conceptual framework focusses on three key areas related to the implementation of the carrier bag levy: (1) accountability; (2) corporate social responsibility; and (3) scheme income allocation. Under accountability, we explore how retailers envisage the scheme as a means to reduce carrier bag usage by their clients and how they perceive their line of responsibility in the implementation of the scheme. Under corporate social responsibility, we examine how retailers use the scheme to deliver their social duties within the communities where they operate. Under scheme income allocation, we analyze the various ways in which the funds generated from selling the carrier bags are used and assess how these new funds contribute to the retailers' corporate objectives.

\section{Data Analysis}

Thematic analysis is followed in the evaluation of the study data. This method is considered effective due to its flexibility in terms of theoretical selection and generating patterns in the collected data (Braun and Clarke, 2006). The six steps outlined by Braun and Clarke (2006) for better implementations of thematic analysis are carefully followed in this paper. First, the data are transcribed based on the research questions and main concepts related to environmental taxation and CSR. Second, codes are created, and data with the same meaning and implication are collated. Third, the collated data are organized into themes considering the relevance of the data to each theme. Fourth, themes are refined based on their cohesion and validity. A clean framework representing the whole dataset organized in terms of themes is obtained at the end of this step. Fifth, themes are given specific names and defined in the context of environmental taxation and CSR. This also takes into consideration the different aspects of the data covered by the themes. The scope and issues relevant to each theme are fully identified in this step. In the final step, the extracted themes are analyzed in line with the study research questions and a relevant literature review is performed. The research themes are manipulated hierarchically based on the study aims and questions as suggested by Richards and Richards (1995). The number of times in which the theme appears in the data is 
used to capture its importance to the research aims. Relationships among the identified themes are also considered as part of the interpretation of the data.

\section{Research Findings and Discussion}

Casual observations of shopping patterns across UK supermarkets, in particular, suggest that shoppers at one store are seen with carrier bags from the same or another store, which would imply that shoppers are reluctant to pay for carrier bags every time they visit a store. This observation would add credibility to the Government's objective to fight pollution caused by carrier bags. Nonetheless, anecdotal evidence gathered from the UK stores suggests that an equal number of shoppers pay for the carrier bags rather than recycle them. Furthermore, the more expensive the store, the more likely it is that its customers will pay for carrier bags (it also suggests that usage of these bags may depend on socioeconomic factors). Customers at stores like NEXT and John Lewis, for instance, are more likely to pay for carrier bags than customers at the supermarkets. This suggests that the effectiveness to reduce consumption of carrier bags depends to a certain extent on the value of the goods. Stores that sell higherpriced items find more customers paying for carrier bags than stores selling lower-priced ones do. This partially supports the findings of Dikgang et al. (2012) that small charges such as the plastic bag levy may not deter individuals from buying the bags subject to the fact that the price or the value of the item(s) they buy is much higher than the cost of the bag. This raises the following questions: what is the business case for the introduction of the levy, and what are the benefits attained by retailers from the scheme?

\section{The Business Case}

While most of the published papers reviewed so far evaluated the carrier bag levy from environmental, public policy or consumer behavior perspectives (for instance, Convery et al. 2007; Zen et al. 2013), we study the levy from a different angle. We examine the approach taken by retailers in implementing the carrier bag levy. We argue that businesses are consciously using the regulation to propagate their marketing presence. This levy is a different type of marketing tool at the disposal of retailers. It is pseudo-cost-free to retailers, and it has many good intentions attached to it. To retailers, the "thicker reusable" carrier bags provide a space for them to fine-tune their marketing appeal. 
This state of affairs causes retailers to invest in the designs of the bags to increase the odds that the customers will reuse their bags instead of competitors' bags. Pre-levy, the cost of designing and manufacturing these bags fell directly on the stores without any accompanying income. However, now that stores charge customers for the bags, the revenue from the sale provides them with extra resources to invest in the bag's design and quality.

Certainly, the quality of the bags has improved from prior to after the advent of the carrier bag levy. Besides, the goal of the levy is to promote reuse of the carrier bags and, consequently, stores have to fabricate bags that are more durable. The fact that customers are paying for these bags implies that they will reuse the bags on more than one occasion. For instance, many customers use the same bag for various purposes including visiting other shops, visiting their families, and attending social functions. In the process, they end up carrying the sponsor's message to a wider audience. The customers are inadvertently acting as a brand ambassador for the store.

Following the levy, fewer of these bags are thrown away after their first use. They are creating less pollution and, consequently, the sponsor's message on the bags benefits from their cleaner handling. A report by The Telegraph shows that within the first six months of introducing the policy the total number of bags used fell by more than $70 \%$ across all large supermarkets leading to dramatic cuts in carrier bag waste (Morley 2016).

\section{Carrier Bag Levy and Social Responsibility}

As illustrated in Table 1, most retailers promote their image as supporters of communitybased projects by donating the funds collected from carrier bag sales to good causes within the communities. There are five main terms used by retailers to denote the high emphasis placed on communities: (1) local community investment; (2) charitable donations; (3) environment donations; (4) educational programs' support; and (5) research grants. Retailers, however, adopt different approaches to the allocation of funds to each of these areas. For example, Marks and Spencer equally split the amount granted to local and national charities. At Wilkinson, the collected funds are used to support various charities including those working on green projects, sustainability and health. While some retailers, such as Tesco, focus on creating outdoor spaces, in the case of Iceland and Boots more weight is given to funding research on dementia and supporting children in need, respectively. In some cases, retailers are even working together in financing some projects through funds collected from 
the plastic bag levy. For example, Asda, Morrison, Iceland, and Waitrose are collectively funding dementia research centers.

Table 1: Carrier Bags' Social Responsibility and Ethics Item Disclosure by the 15Largest Retailers in England

\begin{tabular}{|c|c|c|c|}
\hline Themes & Items Disclosed & Frequency & Examples \\
\hline \multirow[t]{3}{*}{ Community } & 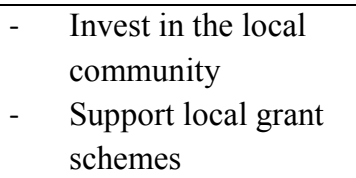 & $\begin{array}{l}\text { Tesco: } 6 \\
\text { Marks \& Spencer: } 1 \\
\text { Cooperative Group: } 4 \\
\text { Boots: } 2\end{array}$ & $\begin{array}{l}\text { Fund a large number of } \\
\text { local projects to create or } \\
\text { improve outdoor spaces in } \\
\text { communities (Tesco) }\end{array}$ \\
\hline & $\begin{array}{ll}\text { - } & \begin{array}{l}\text { Donate to local } \\
\text { charities }\end{array} \\
\text { - } & \begin{array}{l}\text { Donate to national } \\
\text { charities }\end{array} \\
\text { - } & \begin{array}{l}\text { Donate to TV } \\
\text { charitable projects }\end{array} \\
\text { - } & \begin{array}{l}\text { Support children's } \\
\text { education programs }\end{array}\end{array}$ & $\begin{array}{l}\text { Sainsbury: } 2 \\
\text { Asda: } 1 \\
\text { Morrison: } 1 \\
\text { Marks \& Spencer: } 2 \\
\text { Boots: } 1 \\
\text { Home Retail Group: } 1 \\
\text { Next: } 1\end{array}$ & $\begin{array}{ll}\text { - } & \text { Award grants for charity } \\
\text { - } & \text { Dojects (Asda) } \\
\text { in Need (Boots) } \\
\text { - } & \text { Donate to disadvantaged } \\
\text { children } \\
\text { (Home Retail Group) }\end{array}$ \\
\hline & $\begin{array}{ll}- & \text { Fund research } \\
\text { - } & \text { Donate to } \\
\text { environment-related } \\
\text { projects }\end{array}$ & $\begin{array}{l}\text { Asda: } 1 \\
\text { Boots: } 1 \\
\text { Aldi: } 1 \\
\text { Iceland: } 1 \\
\text { Lloyds Pharmacy: } 1 \\
\text { Wilko: } 4\end{array}$ & $\begin{array}{ll}\text { - } & \text { Fund dementia research } \\
\text { center (Asda) }\end{array}$ \\
\hline $\begin{array}{l}\text { Customer Share } \\
\text { of Responsibility }\end{array}$ & $\begin{array}{ll}\text { - } & \text { Promote customers } \\
\text { use of bag for life } \\
\text { - } & \text { Remove carrier bags } \\
\text { from sight } \\
\text { - } \quad \text { Encourage } \\
\text { customers to take } \\
\text { their used bags to } \\
\text { shops } \\
\text { Educate customers } \\
\text { on recycling }\end{array}$ & $\begin{array}{l}\text { Sainsbury: } 2 \\
\text { Waitrose: } 1 \\
\text { Cooperative Group: } 5\end{array}$ & $\begin{array}{l}\text { Promote the use of bag } \\
\text { for life through signage } \\
\text { and customer awareness } \\
\text { (Sainsbury) }\end{array}$ \\
\hline Sustainability & $\begin{array}{ll}- & \text { Promote } \\
& \text { sustainability } \\
- & \text { Increase use of }\end{array}$ & $\begin{array}{l}\text { Sainsbury: } 3 \\
\text { Waitrose: } 1 \\
\text { Lloyds Pharmacy: } 1\end{array}$ & 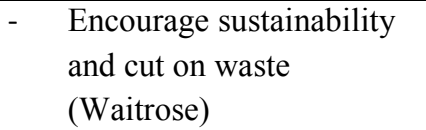 \\
\hline
\end{tabular}

\footnotetext{
${ }^{7}$ The British Broadcasting Corporation

${ }^{8}$ The University College London
} 


\begin{tabular}{|c|c|c|c|}
\hline & recycling bags & Primark: 1 & $\begin{array}{l}\text { - Offer sustainable bags to } \\
\text { customers (Lloyds } \\
\text { Pharmacy) }\end{array}$ \\
\hline
\end{tabular}

The review of the retailers'online reports shows that not all retailers promote the use of bag for life and educate their customers on recycling. Out of the 15 retailers examined only three provide explicit information on the approach taken to increase customers' awareness of using a bag for life and helping them to reduce their use of other carrier bags through signage and removing the bags from sight. The Cooperative group followed by Sainsbury are among the retailers that consider their customers at the center of reducing the use of plastic bags and educating them on the benefits that accrue from such practice. Such an approach should be extended to other retailers to make customers more appreciative of the scheme rather than perceiving the charge as an additional cost which is imposed upon them with the aim to reduce the usage of carrier bags.

The reports indicate that only a small number of retailers perceive the carrier bag levy as a means to improve sustainability in society. Among the retailers that hold such a view are Sainsbury, Waitrose, Lloyds Pharmacy and Primark. Waitrose, for example, envisages the levy as a tool to cut down on waste and promote sustainability, while Sainsbury and Lloyds Pharmacy report that their bags are reusable and recyclable. Such a notion is also shared by Primark which uses paper bags rather than plastic ones as they are considered to be more environmentally friendly. These perceptions are in line with Ritch et al. (2009) view of the carrier bag levy as a way to promote sustainability and improve the environment.

\section{The Benefits to the Community}

The reporting of plastic bag sales is sporadic and inconsistent, and only five of the 15 stores surveyed report any data on their website. Nonetheless, given the importance of curtailing plastic bag usage environmentally, many stores do not account for the expenses related to the implementation of the levy (for example, compliance costs and expenses associated with informing the public about the scheme) in pricing their products. The retailers collectively note that the net proceeds received are used in line with the Department for Environment, Food \& Rural Affairs guidelines to donate the money for good causes. Next, we consider the use of the proceeds from the sale of the carrier bags.

Morrisons, for instance, donated the net proceeds received from selling the carrier bags in 2015/16 to Morrisons Foundation (89.76\%), the national charity Sue Ryder (6.83\%), and to 
support the construction of the Dementia Research Centre (3.41\%). Tesco has also passed on the net revenue from sales of carrier bags in its Welsh stores to the Royal Society for the Protection of Birds. ${ }^{9}$ The point is that the stores now have funds to broaden their appeal socially. Donating to good causes like the environment, education, health, arts and for charitable causes should translate into more goodwill toward the stores. If the retailers decide to channel the extra revenue to CSR-related activities and the Government helps report this, then the Government is helping to promote the retailer as a community champion, at no extra cost to the retailer. CSR also allows retailers to create bridges with the community where they are located, which will help them retain their existing clients and improve their overall satisfaction. In a news article by Asda in 2015, it is noted that the retailers including the likes of Iceland, Morrisons, and Waitrose were to use the income generated from carrier bag charges to help fund the construction of a new Dementia Research Centre. This initiative is evidence of the retailers' goodwill to co-operate and use the funds collected from selling the carrier bags to finance projects that benefit local communities.

\section{Misuse of the Levy}

While each supermarket commits some funds to good causes, the amount donated tends to vary widely from one retailer to another. A Guardian Newspaper article reports that Sainsbury's, for example, only pays the equivalent of $1 p$ per bag of the net proceeds; Tesco pays $3 p$, and Morrisons, Asda, and Waitrose all pay the full net proceeds of $4.16 \mathrm{p} .^{10}$ The variation in the amount paid is attributed to the type of bag used by each retailer, which means some of them are not subject to the same legislative rules. In this regard, the real motives of the retailers remain indistinct. On the one hand, they claim they are helping to combat pollution, support local communities and announce extreme measures; for instance, Lidl announced in September 2016 that it would ban single-use carrier bags starting 2017 i.e. its customers will not be able to buy 5 p disposable carrier bags from its stores. ${ }^{11}$ Equally, Lidl will introduce 9 pence reusable bags for sale starting from July 2017 and has no plans to donate any of the sale proceeds. Thus, it is impossible not to think that some retailers will retain part of the money made from the sale of reusable bags to boost profits. The retailers

\footnotetext{
${ }^{9}$ Source: http://www.economist.com/news/britain/21670047-do-you-really-need-keep-40-carrier-bags-homehelping-hoarders

${ }^{10} \mathrm{See}$ https://www.theguardian.com/business/2016/feb/21/sainsburys-lags-behind-rivals-in-plastic-bag-charitydonations- $1 \mathrm{p}$

${ }^{11} \mathrm{http}: / /$ www.telegraph.co.uk/news/2016/09/28/lidl-bans-5p-single-use-plastic-bags-but-plans-to-makemillions/
} 
argue that the $5 \mathrm{p}$ bag is not fit for reuse while the more expensive bags would be fit for multiple uses, thus reducing avoidable waste.

During this study, we observe some inconsistencies in the manner in which competing supermarkets manage the carrier bag levy. We particularly observe three areas that raise concern and accentuate our position in this study. The first is the varied price-points ranging from the Levy-driven 5p carrier bags across all supermarkets to the variants of 6 pence charged at ASDA and 10 pence at Tesco. Second, while a few of the retailers have been observed to advise customers of the free exchange of returned carrier bags, most have a different policy in place. Consequently, many shoppers are unaware that they can avoid the $5 p$ charge altogether by purchasing thicker, reusable 'bags for life' which can be exchanged for free when they are worn out. Third, while the $5 p$ carrier bags are not readily within sight of customers, the more expensive bags are usually more prominently displayed at check-outs and can be easily grabbed. Collectively, the observations tend to suggest irregularities in the management of the levy in a way that not only confuses customers but also exploits customers to the advantage of the retailers. This has some rather worrying implications for the policy that the legislation was geared towards nurturing-sustainability.

Given the legal grounds to charge for carrier bags, retailers have strategically invested in the provision of better-designed, more attractive, reusable, and better-quality variants - at different price points. This invariably translates to additional costs, to be borne by these retailers, of sourcing such bags. It is persuasive to argue, therefore, that a huge portion of the proceeds may be invested elsewhere, away from the desired social causes anticipated by the Government's legislation. A review of the literature tends to support the fact that while most retailers may have been receptive to the levy, each has its policy on how it dispenses or disburses the proceeds accruing from the charge - beyond the single-use carrier bags. We contend, therefore, that such discrepancies in the behavior of these retailers highlight weak controls in governing the CSR dictates of the legislation.

\section{Conclusion}

The discussions and analyses presented in this paper on the carrier bag levy provide some interesting contributions to theorists and practitioners alike. The levy offers the retailers an avenue for bolstering their carbon footprint because consumers are expected to reuse the carrier bags - i.e. the "bag for life" - as they now have to pay for them. The expectations and 
evidence from certain sources seem to suggest that customers have started using carrier bags more judiciously and, thereby, reducing the harm caused to the environment.

The fact that customers pay for the bags that were free in the past indeed does not guarantee that all of them will reuse the bag. There is limited research about the attitudes and preferences of customers regarding the use of plastic bags. However some studies manifest that customers would like to use and reuse paper shopping bags rather than plastic shopping bags (i.e. Prendergast et al., 2001). Some researchers provided evidence of countries' legislation that had positive effects on customers' bag-use behaviors including bringing one's own bag (see for instance Lam and Chen, 2006). There is also research supporting the use of normative messages that encourage shoppers to use fewer free plastic bags for their shopping in addition to the supermarket's standard environmental approach aimed at reducing plastic bags (De Groot et al. 2013). This method uses implicit and explicit messages accompanied with the implementation of a plastic bag levy in supermarkets in the UK. In Ireland the effect on consumers' behavior has been very relevant with the introduction of 15 Euro cent tax on plastic shopping bags, the effect of the tax on the use of plastic bags in retail outlets has resulted in a reduction of $90 \%$ in using plastic bags (Convery et al. 2007). However, there are some studies showing that the extra cost attributed to the plastic bag levy may not induce the customers to be more environmentally friendly as may be envisaged by the advocates of the levy (Jakovcevic at al. 2014).

Retailers have also bolstered their CSR profile by earning a great deal of goodwill because they donate the proceeds to charitable causes. However, some retailers are finding creative ways to bypass the levy and possibly maximize their profits. For instance, certain stores are discouraging the purchase of the $5 \mathrm{p}$ carrier bags in favor of more durable but higher-priced carrier bags. As carrier bags in the latter category are not covered by the definition of 'single-use' in the legislation, the proceeds from the sales of such carrier bags may not have to be donated to charitable causes. In other words, the retailers may consider such sales as an extra source of income. This, therefore, means that the main beneficiaries of the carrier bag levy in England may well be the retailers who have been, inadvertently, granted the license to exploit the gaps in the legislation.

Irrespective of the legal obligations surrounding the carrier-bag levy, genuine social impact of the levy will depend on how accountable the retailers feel towards society and the environment. Besides the common understanding that the proceeds from the sale of the carrier bags should be spent on CSR-related activities, the effective impact of the levy will only be realized if it is woven into the CSR strategy of affected retailers. This would also 
need to be supported by genuine transparency on how the proceeds from the levy are invested towards CSR activities both in the short term and the long term. Businesses should not be 'parasites' to communities where they operate, but positive contributors to the well-being of people (Garriga and Melé 2004). Therefore, with proper use of resources from the carrier bag levy, retailers have the opportunity to contribute to the common good of the society and position themselves as sustainable and fully responsible towards the environment. 


\section{References}

Aldi, 2016. Giving nature a home. https:/www.aldi.co.uk/about-aldi/corporateresponsibilities/communities/aldi-and-the-rspb (accessed 1 December 2016).

Alliance Boots, 2016. Carrier bags at Boots UK. http://www.bootsuk.com/corporate social responsibility/latest-news/carrier-bags-at-boots-uk.aspx (accessed 1 December 2016).

Anstine, J., 2000. Consumers' willingness to pay for recycled content in plastic kitchen garbage bags: a hedonic price approach. App. Eco. Let. 7(1), 35-39.

Antal, A.B., Dierkes, M., MacMillan, K., Marz, L., 2002. Corporate social reporting revisited. J. Gr. Man. 28(2), 22-42

Asda, 2015. Carrier bag charges in England will fund new dementia research centre. http://your.asda.com/news-and-blogs/carrier-bag-charges-england-2015 (accessed 24 November 2016).

Ayalon, O., Goldrath, T., Rosenthal, G.,Grossman, M., 2009. Reduction of plastic carrier bag use: An analysis of alternatives in Israel. Wa. Man. 29(7), 2025-2032.

Bansal, P., 2005. Evolving sustainably: a longitudinal study of corporate sustainable development. Stra. Man. J. 26(3), 197-218.

Bondy, K., Moon, J., Matten, D.,2012. An institution of corporate social responsibility (CSR) in multi-national corporations (MNCs): Form and implications. J. Bus. Eth. 111, 281299.

Bourgeon, J.M., Ollivier, H., 2012. Is bioenergy trade good for the environment? Eur. Eco. Rev. 56(3), 411-421

Braun, V., Clarke, V. 2006. Using thematic analysis in psychology. Qual. Res. Psych. 3, 77101.

British Retail Consortium, 2001, Towards retail sustainability, British retail consortium,London.http://www.fcrn.org.uk/research-library/british-retail-consortiumprogress-report-better-retailing-climate-towards(accessed 18 August 2017).

Carroll, A.B.,1991. The pyramid of corporate social responsibility: Toward the moral management of organizational stakeholders. Bus. Hor. 34, 39-48.

Chao, C.C., Hu, S.W., Lai, C.C., Tai, M.Y.,2012. Foreign aid, government spending and the environment. Rev.Dev. Eco. 16(1), 62-71.

Chow, L., 2016. Fantastic news: England's plastic bag usage drops by $85 \%$. http://www.ecowatch.com/england-plastic-bag-usage-drops-85-1956159456.html. (accessed 2 August 2016).

Cooperative Group, 2016. A lot less waste, bags more for your community! http://www.cooperativefood.co.uk/carrier-bags (accessed 28 November 2016).

Cone Communications \& Echo, 2012. 2011 Cone/Eco global opportunity. http://www.coneinc.com/stuff/contentmgr/files/0/2fcb9351e2bea95addb6c4413bcf39 a4/files/2011_cone echo_global_cr_opportunity_study.pdf. (accessed 5 June 2013).

Convery, F., McDonnell, S., Ferreira, S., 2007. The most popular tax in Europe? Lessons from the Irish plastic bags levy. Env. Res. Eco. 38(1), 1-11.

Durieu, X. 2003, How Europe's retail sector helps promote sustainable production and consumption, Ind. \& Env. 26(1), 7-10

Crane, A., Palazzo, G., Spence, L.J., Matten, D., 2014. Contesting the value of "creating shared value". Cal. Man. Rev. 56(2), 130-153.

De Groot, J. I., Abrahamse, W., Jones, K. 2013. Persuasive normative messages: The influence of injunctive and personal norms on using free plastic bags. Sus. 5(5), $1829-1844$.

Department for Environment, Food and Rural Affairs. 2017. Carrier bags: why there's a charge. Policy paper. Revised $31^{\text {st }}$ July 2017. 
https://www.gov.uk/government/publications/single-use-plastic-carrier-bags-whywere-introducing-the-charge/carrier-bags-why-theres-a-5p-charge (accessed 21 September 2017).

Dickson, M.A., Loker, S., Eckman, M., 2009. Social responsibility in the global apparel industry. Fairchild Books, New York.

Dikgang, J., Leiman, A., Visser, M., 2012. Analysis of the plastic-bag levy in South Africa. Res. Cons.Rec. 66, 59-65.

Elkington, J., 1994. Towards the suitable corporation: win-win-win business strategies for sustainable development. Cal. Man. Rev. 36(2), 90-100.

Ekins, P., Barker, T., 2001. Carbon taxes and carbon emissions trading. J. Eco. Sur. 15(3), 325-376.

Ekins, P., Speck, S., 1999. Competitiveness and exemptions from environmental taxes in Europe. Env. Res. Eco. 13, 369-399.

Feng, K., Hubacek, K., Guan, D., Contestabile, M., Minx, J., Barrett, J., 2010. Distributional effects of climate change taxation: the case of the UK. Env. Sci.Tech. 44(10), 3670 3676.

Forrer, J., Kee, J.E., Newcomer, K.E., Boyer, E., 2010. Public-private partnerships and the public accountability question. Pub. Adm. Rev. 70(3), 475-484.

Garriga, E., Melee, D., 2004. Corporate social responsibility theories: Mapping the territory. J. Bus. Eth. 53(1), 51-71.

Gosden, E., 2015. Carrier bag 5p charge: everything you need to know. http://www.telegraph.co.uk/news/11892387/Carrier-bag-5p-charge-everything-youneed-to-know.html (accessed 2 December 2016).

Gunn, W., Løgstrup, L., 2014.Participant observation, anthropology methodology and design anthropology research inquiry. Art. Hum. High. Edu. 13(4), 428-442.

Hayes, R.S., Baker, R. 2014. A participant observation study of the resolution of audit engagement challenges in government tax compliance audits. Qual. Res. Acc.\& Man., 1(4), 416-439.

Home Retail Group, 2016. Keeping clean and green. https://www.homeretailgroup.com/corporate-responsibility/keeping-clean-and-green/ (accessed 1 December 2016).

Iceland, 2016. What does Iceland do with the money raised on carrier bags? http://help.iceland.co.uk/knowledgebase/articles/743820-what-does-iceland-do-withthe-money-raised-on-carr (accessed 3 December 2016).

Jakovcevic, A., Steg, L., Mazzeo, N., Caballero, R., Franco, P., Putrino, N., Favara, J. 2014. Charges for plastic bags: Motivational and behavioral effects. J. Env. Psy., 40, 372 380.

Jones, P., Comfort, D., Hillier, D.,Eastwood, I., 2005. Retailers and sustainable development in the UK. Int. J. Ret. Dis. Man. 33(3), 207-214.

Lai, K.H., Cheng, T.C.E., Tang, A.K.Y., 2010. Green retailing: Factors for success, Cal. Man. Rev. 52(2), 6-31.

Lloyds Pharmacy, 2016. Lloyds Pharmacy carrier bags support UK Alzheimer's charities. http://celesio.co.uk/2016/10/04/lloydspharmacy-carrier-bags-support-uk-alzheimerscharities/ (accessed 3 December 2016).

Luís, I.P., Spínola, H., 2010. The influence of a voluntary fee in the consumption of plastic bags on supermarkets from Madeira Island (Portugal). J.Env. Plan. Man. 53(7), 883889.

Lam, S. P., Chen, J. K. 2006. What makes customers bring their bags or buy bags from the shop? A survey of customers at a Taiwan hypermarket. Env. \& Beh., 38(3), 318-332. 
Mamic, I., 2008. Managing global supply chain: The sports footwear, apparel and retail sectors. J. Bus. Eth. 59(1-2), 81-100.

Marks \& Spencer, 2016. Why does M\&S charge for carrier bags? http://help.marksandspencer.com/support/company-website/carrier-bags (accessed 28 November 2016).

Ministry of Environment and Food of Denmark. Environmental Protection Agency. 2018. Life Cycle Assessment of grocery carrier bags. Environmental Project no. 1985. Accessed at: https://www2.mst.dk/Udgiv/publications/2018/02/978-87-93614-734.pdf (accessed 06 October 2018).

Miranda, M.L., Hale, B.W., 2002. A taxing environment: Evaluating the multiple objectives of environmental taxes. Env. Sci. Tech. 36(24), 5289-5295.

Morley, K., 2016. Lidl bans 5p single-use plastic bags BUT could make millions through 9p re-usable carriers. http://www.telegraph.co.uk/news/2016/09/28/lidl-bans-5p-singleuse-plastic-bags-but-plans-to-make-millions/ (accessed 1 December 2016).

Morrisons, 2016. Carrier bag charging in the UK. http://www.morrisonscorporate.com/cr/our-carrier-bag-savings-in-the-uk/ (accessed 28 November 2016).

Next, 2016. Carrier nag charges in England, Scotland and Wales. http://help.next.co.uk/Section.aspx?ItemId=24750 (accessed 2 December 2016).

Nielsen Report on Sustainability, 2015. The Sustainability Imperative http://www.nielsen.com/content/dam/nielsenglobal/dk/docs/global-sustainabilityreport-oct (accessed 2 March 2015).

OECD, 2010. Taxation, innovation and the environment. OECD, Paris.

Oliver, J., Eales, K. 2008. Research ethics: Re-evaluating the consequentialist perspective of using covert participant observation in management research.Qua. Mar. Res.: Int. J. 11(3), 344-357.

Park, J., 2009. The search for another way to shop. Packaging News (February), 28-29.

Pigou, A., 1920. The Economics of Welfare.Macmillan, London.

Porter, M.E., 1987. From competitive advantage to corporate strategy. Har.Bus. Rev.65(3), 43-59.

Porter, M., Kramer, M.R., 2011. Creating shared value: How to reinvent capitalism - and unleash a wave of innovation and growth. Har. Bus.Rev. 89(1/2), 62-77.

Porter, M.E., Kramer M.R.,2006. Strategy and society:The link between competitive advantage and corporate social responsibility.Har.Bus. Rev. 84, 78-91.

Prendergast, G., Wai Ng, S., Lee Leung, L. 2001. Consumer perceptions of shopping bags. Mar. Int. \& Pla., 19(7), 475-482.

Primark, 2016. Our responsibility. https://www.primark.com/en/about-us/our_responsibility (accessed 2 December 2016).

Ritch, E., Brennan, C.,MacLeod, C., 2009. Plastic bag politics: modifying consumer behaviour for sustainable development. Int. J. Con. Stu. 33(2), 168-174.

Rivers, N., Shenstone-Harris, S., Young, N., (2017). Using nudges to reduce waste? The case of Toronto's plastic bag levy. J. Env. Man. 188, 153-162.

Roberts, J.,2001. Trust and control in Anglo-American systems of corporate governance: The individualizing and socializing effects of processes of accountability. Hum. Rel. 54(12), 1547-1572.

Rocchi, M., Ferrero, I., 2014. Shared value in finance: Revisiting shared value in light of the person-centered approach. Working Paper $n^{\circ}$ 07/14, School of Economics and Business, University of Navarra, Spain.

Rondinelli, D.A., Berry, M.A., 2000. Environmental citizenship in multinational corporations: Social responsibility and sustainable development. Eur. Man. J. 18, 7084. 
Sælen, H.,Kallbekken, S., 2011. A choice experiment on fuel taxation and earmarking in Norway. Ecol. Eco. 70(11), 2181-2190.

Zen, I.S., Ahamad, R., Omar, W., 2013. No plastic bag campaign day in Malaysia and the policy implication. Env. Dev. Sus. 15(5), 1259-1269.

Sainsbury, 2015. Carrier Bags. http://www.j-sainsbury.co.uk/responsibility/casestudies/2015/carrier-bags/ (accessed 24 November 2016).

Shaw, D., Hogg, G., Wilson, E., Shui, E., Hassan, L., 2006. Fashion victim: the impact of fair trade concerns on clothing choice. J.Stra. Mar. 14(4), 427-440.

Sivagnanasundaram, M. 2018. Sustainability practices in Indian retail industry: A comparison with top global retailers. Emer. Eco. Stu. 4(1), 102-111.

Swift, T., 2001. Trust, reputation and corporate accountability to stakeholders. Bus. Eth.: A Eur. Rev. 10(1), 16-26.

Tedlock, B. 2000. Ethnography and ethnographic representation. In N.K. Denzin., Y.S.Lincoln (Eds.),Handbook of qualitative research, 455-484. Thousand Oaks,CA: Sage.

Tesco, 2016. Bags of help. http://www.tesco.com/carrier-bags/ (accessed 24 November 2017).

Thomas, G.O., Poortinga, W.,Sautkina, E., 2016. The Welsh single-use carrier bag charge and behavioural spillover. J.Env. Psych. 47, 126-135.

Tickner, J.A., Geiser, K. 2004. The precautionary principle stimulus for solutions- and alternatives-based environmental policy. Env. Imp. Ass. Rev. 24, 801-824.

United Nations Environment Programme. 2003. Shopping for a better world: Facts and figures. Ind. \&Env. 26(1), 4-6.

Varadarajan, P., Menon, A., 1988. Cause-related marketing: A coalignment of marketing strategy and corporate philanthropy. J. Mar.52(3), 58-74.

Waitrose, 2016. Packaging and recycling. http://www.waitrose.com/home/inspiration/about_waitrose/the_waitrose_way/packagi ng(accessed 28 November 2017).

Wilkinson (2016). We've got charity in the bag. http://corporate.wilko.com/stories/carrierbagEngland.php (accessed 3 December 2016). 